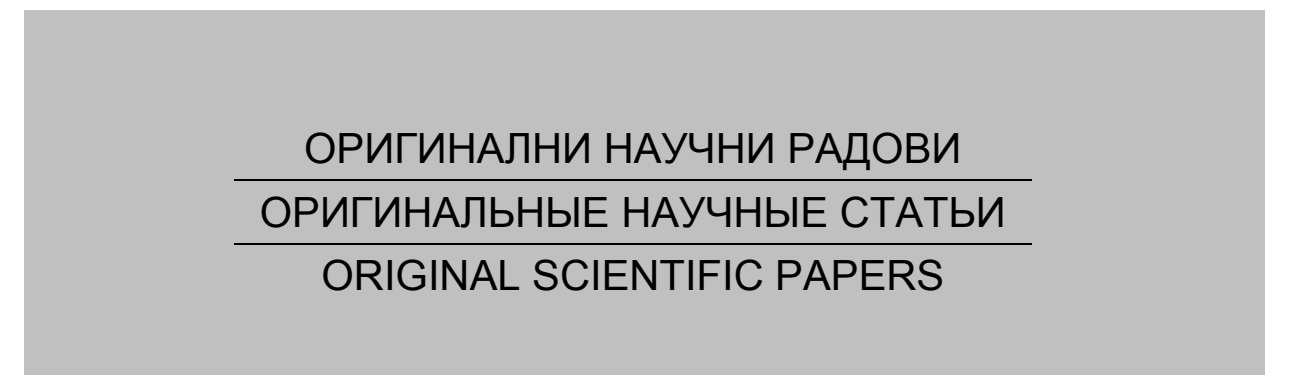

\title{
SPECTRUM AND ENERGY OF THE SOMBOR MATRIX
}

\author{
Ivan Gutman \\ University of Kragujevac, Faculty of Science, \\ Kragujevac, Republic of Serbia, \\ e-mail: gutman@kg.ac.rs, \\ ORCID iD: (Dhttps://orcid.org/0000-0001-9681-1550
}

DOI: 10.5937/vojtehg69-31995; https://doi.org/10.5937/vojtehg69-31995

FIELD: Mathematics (Mathematics Subject Classification: primary 05C50, secondary 05C07)

ARTICLE TYPE: Original Scientific Paper

Abstract:

Introduction/purpose: The Sombor matrix is a vertex-degree-based matrix associated with the Sombor index. The paper is concerned with the spectral properties of the Sombor matrix.

Results: Equalities and inequalities for the eigenvalues of the Sombor matrix are obtained, from which two fundamental bounds for the Sombor energy (= energy of the Sombor matrix) are established. These bounds depend on the Sombor index and on the "forgotten" topological index.

Conclusion: The results of the paper contribute to the spectral theory of the Sombor matrix, as well as to the general spectral theory of matrices associated with vertex-degree-based graph invariants.

Keywords: Sombor matrix, Sombor energy, Sombor index, vertexdegree-based graph invariant, spectrum (of matrix).

\section{Introduction}

In this paper, we are concerned with simple graphs, i.e., graphs without directed, weighted, or multiple edges, and without self-loops. Let $G$ be such a graph, with the vertex set $V(G)$ and the edge set $E(G)$. Let $|V(G)|=n$ and $|E(G)|=m$ be the number of vertices and edges of $G$. By $u v \in E(G)$ we denote the edge of $G$, connecting the vertices $u$ and $v$. The degree (= number of first neighbors) of a vertex $u \in V(G)$ is 
denoted by $d(u)$. If $d(u)=r$ for all $u \in V(G)$, then $G$ is said to be a regular graph or a degree $r$.

For other graph-theoretical notions, the readers are referred to standard textbooks (Harary, 1969), (Bondy \& Murthi, 1975).

In the mathematical and chemical literature, degree-based graph invariants of the form

$$
T I(G)=\sum_{u v \in E(G)} f(d(u), d(v))
$$

have been and are currently studied, where $f(x, y)$ is an appropriately chosen function with the property $f(x, y)=f(y, x)$. The oldest such invariants were put forward as early as in the 1970s, and by now their number exceeds several dozens (Kulli, 2020), (Todeschini \& Consonni, 2009). Among the newest invariants of this type are the forgotten index for which $f(x, y)=x^{2}+y^{2}$ (Furtula \& Gutman, 2015), and the Sombor index for which $f(x, y)=\sqrt{x^{2}+y^{2}}$ (Gutman, 2021). Thus, these indices are defined as

$$
\begin{aligned}
& F(G)=\sum_{u v \in E(G)}\left[d(u)^{2}+d(v)^{2}\right] \\
& S O(G)=\sum_{u v \in E(G)} \sqrt{d(u)^{2}+d(v)^{2}} .
\end{aligned}
$$

Recall that $F$ is often written in the form

$$
F(G)=\sum_{u \in V(G)} d(u)^{3}
$$

which, of course, is equivalent to (2).

The first paper on the Sombor index was published only a few months ago (Gutman, 2021). Because this graph invariant is based on using Euclidean metrics, it promptly attracted the attention of quite a few colleagues. As a consequence of this, numerous papers on Sombor index have already been published (Alikhani \& Ghanbari, 2021), (Cruz \& Rada, 2021), (Došlić et al, 2021), (Horoldagva \& Xu, 2021), (Kulli, 2021), and more will appear in the near future. Bearing this in mind, we were motivated to investigate the matrix constructed from the Sombor index in 
an earlier proposed manner (Das et al, 2018), and to study some of its spectral properties.

Let the vertices of the graph $G$ be labeled by $1,2, \ldots, n$. Then the $(0,1)$-adjacency matrix of $G$, denoted by $A(G)$, is defined as the symmetric square matrix of order $n$, whose $(I, j)$-element is

$$
A(G)_{i j}= \begin{cases}1 & \text { if } i j \in E(G) \\ 0 & \text { if } i j \notin E(G) \\ 0 & \text { if } i=j .\end{cases}
$$

The eigenvalues of $A(G)$ form the spectrum of the graph $G$. For the details of the spectral graph theory see (Cvetković et al, 2010).

Some time ago (Das et al, 2018), it was attempted to combine the spectral graph theory with the theory of vertex-degree-based graph invariants. For this, using formula (1), an adjacency-matrix-type square symmetric matrix $A_{F}(G)$ was introduced, whose $(I, j)$-element is defined as

$$
A_{F}(G)_{i j}= \begin{cases}f(d(i), d(j)) & \text { if } i j \in E(G) \\ 0 & \text { if } i j \notin E(G) \\ 0 & \text { if } i=j .\end{cases}
$$

The theory based on the matrix $A_{F}(G)$ and its spectrum was recently elaborated in some detail (Li \& Wang, 2021), (Shao et al, 2021).

In this paper, we examine a special case of $A_{F}(G)$, associated with the Sombor index $S O(G)$, Eq. (3). We call it the Sombor matrix, denote it by $A_{\text {So }}(G)$, and define via

$$
A_{\mathrm{SO}}(G)_{i j}= \begin{cases}\sqrt{d(i)^{2}+d(j)^{2}} & \text { if } i j \in E(G) \\ 0 & \text { if } i j \notin E(G) \\ 0 & \text { if } i=j .\end{cases}
$$


The eigenvalues of $A_{\mathrm{SO}}(G)$ are denoted by $\sigma_{1}, \sigma_{2}, \ldots, \sigma_{n}$, and are said to form the Sombor spectrum of the graph $G$. Then, as usual, the Sombor characteristic polynomial is defined as

$$
\phi_{S O}(G, \lambda)=\operatorname{det}\left(\lambda I_{n}-A_{\text {SO }}(G)\right)
$$
2010)

in analogy to the ordinary characteristic polynomial (Cvetković et al,

$$
\phi(G, \lambda)=\operatorname{det}\left(\lambda I_{n}-A(G)\right)
$$

where $I_{n}$ is the unit matrix of order $n$. Recall that $\sigma_{1}, \sigma_{2}, \ldots, \sigma_{n}$ are the zeros of $\phi_{S O}(G, \lambda)$, i.e., satisfy $\phi_{S O}\left(G, \sigma_{i}\right)=0$ for $1,2, \ldots, n$.

\section{Spectral properties of the Sombor matrix}

Lemma 1. Let $\sigma_{1} \geq \sigma_{2} \geq \cdots \geq \sigma_{n}$ be the eigenvalues of the Sombor matrix. Then,

$$
\sum_{i=1}^{n} \sigma_{i}=0
$$

and

$$
\sum_{i=1}^{n} \sigma_{i}^{2}=2 F(G)
$$

where $F(G)$ is the forgotten topological index, Eq. (2).

Proof. The first equality is a direct consequence of $A_{S O}(G)_{i i}=0$ for all $1,2, \ldots, n$.

The second equality is obtained from (4) as follows. Suppose that the vertices of $G$ are labeled by $1,2, \ldots, n$. Then, 


$$
\begin{aligned}
& \sum_{i=1}^{n} \sigma_{i}^{2}=\operatorname{Tr}\left(A_{\mathrm{SO}}(G)^{2}\right)=\sum_{i=1}^{n} \sum_{j=1}^{n} A_{\mathrm{SO}}(i, j) A_{\mathrm{SO}}(j, i) \\
= & 2 \sum_{i j \in E(G)} A_{S O}(i, j) A_{S O}(j, i)=2 \sum_{i j \in E(G)} \sqrt{d(i)^{2}+d(j)^{2}} \sqrt{d(j)^{2}+d(i)^{2}} \\
= & 2 \sum_{i j \in E(G)}\left[d(i)^{2}+d(j)^{2}\right]=2 F(G) .
\end{aligned}
$$

This completes the proof of Lemma 1.

Recalling that the sum of squares of the eigenvalues of the ordinary adjacency matrix is equal to $2 m$, from Lemma 1 we realize that in the spectral theory of the Sombor matrix, the forgotten topological index plays an analogous role as the number of edges plays in the ordinary spectral graph theory. This will be seen from the bounds for the Sombor energy, deduced in the forthcoming section (Theorems 1, 2, and 3).

Lemma 2. Let $\sigma_{1}$ be the greatest eigenvalue in the spectrum of the Sombor matrix. Then,

$$
\sigma_{1} \geq 2 \frac{S O(G)}{n}
$$

where $S O(G)$ is the Sombor index, Eq. (3). Equality is attained if and only if the graph $G$ is regular.

Proof. According to the Rayleigh-Ritz variational principle, if $\Omega$ is any $n$-dimensional column-vector, then

$$
\frac{\Omega^{T} A_{\mathrm{SO}}(G) \Omega}{\Omega^{T} \Omega} \leq \sigma_{1} .
$$

Setting $\Omega=(1,1, \ldots, 1)^{T}$, we get 


$$
\begin{aligned}
\Omega^{T} A_{S O}(G) \Omega & =\sum_{i=1}^{n} \sum_{j=1}^{n} A_{S O}(G)_{i j}=2 \sum_{i j \in E(G)} A_{S O}(G)_{i j} \\
& =2 \sum_{i j \in E(G)} \sqrt{d(i)^{2}+d(j)^{2}}=2 S O(G)
\end{aligned}
$$

and

$$
\Omega^{T} \Omega=n .
$$

In the case of regular graphs, $\Omega=(1,1, \ldots, 1)^{T}$ is an eigenvector of $A_{\text {so }}(G)$, corresponding to the eigenvalue $\sigma_{1}$. To see this, note that if $G$ is a regular graph of a degree $r$, then $A_{S O}(G)=\sqrt{2 r} A(G)$. That $\Omega=(1,1, \ldots, 1)^{T}$ is an eigenvector of $A(G)$ is a well-known fact (Cvetković et al, 2010). Then, and only then, equality in Lemma 2 holds.

By this, the proof of Lemma 2 has been completed.

\section{Sombor energy and its bounds}

The energy $\operatorname{En}(G)$ of a graph $G$ is, by definition, equal to the sum of the absolute values of the eigenvalues of $A(G)$. For the details of the mathematical theory of graph energy see (Li et al, 2012). In analogy to this, we define the Sombor energy of $G$ as

$$
E n_{S O}(G)=\sum_{i=1}^{n}\left|\sigma_{i}\right|
$$

It is now reasonable to expect that $E n_{S O}(G)$ and $E n(G)$ have analogous properties. In what follows, we establish two such results.

Theorem 1. (McClelland-type bound for the Sombor energy)

If $G$ is a graph on $n$ vertices, and $F(G)$ is its forgotten topological index, then

$$
E n_{\text {so }}(G) \leq \sqrt{2 n F(G)} .
$$

This result is the analogue of the classical McClelland bound for graph energy, namely, $\operatorname{En}(G) \leq \sqrt{2 n m}$ (McClelland, 1971). 
Proof. Start with the inequality whose validity is obvious:

$$
\sum_{i=1}^{n} \sum_{j=1}^{n}\left(\left|\sigma_{i}\right|-\left|\sigma_{j}\right|\right)^{2} \geq 0
$$

and take into account Lemma 1 and the definition of $E n_{S O}(G)$. The McClelland-type upper bound for $E n_{S O}(G)$ follows then from (5) by direct calculation.

Equality in Theorem 1 will hold if and only if $\left|\sigma_{1}\right|=\left|\sigma_{2}\right|=\cdots=\left|\sigma_{n}\right|$. Graphs that satisfy this equality condition are the edgeless graph (for which $m=0$ ) and the regular graph of degree 1 .

Theorem 2. (Koolen-Moulton-type bound for the Sombor energy)

Let $G$ be a graph on $n$ vertices, with Sombor and forgotten indices $S O(G)$ and $F(G)$, respectively. Then

$$
E n_{S O}(G) \leq \frac{2 S O(G)}{n}+\sqrt{(n-1)\left[2 F(G)-\left(\frac{2 S O(G)}{n}\right)^{2}\right]}
$$

which is the analogue of the Koolen-Moulton bound (Koolen \& Moulton, 2001), namely

$$
E n(G) \leq \frac{2 m}{n}+\sqrt{(n-1)\left[2 m-\left(\frac{2 m}{n}\right)^{2}\right]} .
$$

Proof. We follow the reasoning from the paper (Koolen \& Moulton, 2001), modified for the Sombor energy. In an analogous way as in the proof of Theorem 1, our starting point is

$$
\sum_{i=2}^{n} \sum_{j=2}^{n}\left(\left|\sigma_{i}\right|-\left|\sigma_{j}\right|\right)^{2} \geq 0
$$

from which it follows

$$
\sum_{i=2}^{n}\left|\sigma_{i}\right| \leq \sqrt{2(n-1) F^{*}(G)}
$$

where 


$$
2 F^{*}(G)=\sum_{i=2}^{n} \sigma_{i}^{2}=2 F(G)-\sigma_{1}^{2} .
$$

This yields

$$
E n_{S O}(G)-\left|\sigma_{i}\right| \leq \sqrt{(n-1)\left[2 F(G)-\sigma_{i}^{2}\right]}
$$

and

$$
E n_{S O}(G) \leq \sigma_{i}+\sqrt{(n-1)\left[2 F(G)-\sigma_{i}^{2}\right]}
$$

since $\sigma_{1}>0$.

Consider the function

$$
\psi(x) \leq x+\sqrt{(n-1)\left[2 F(G)-x^{2}\right]} .
$$

It monotonously decreases in the interval $(a, b)$ where

$$
a=\sqrt{\frac{2 F(G)}{n}} \quad \text { and } \quad b=\sqrt{2 F(G)} .
$$

Therefore, inequality (6) remains valid if on the right-hand side of $\psi(x)$, the variable $x$ is replaced by the lover bound for $\sigma_{i}$, from Lemma 2. This results in Theorem 2.

Theorem 3. Let $G$ be a bipartite graph on $n$ vertices, with Sombor and forgotten indices $S O(G)$ and $F(G)$, respectively. Then

$$
E n_{S O}(G) \leq \frac{4 S O(G)}{n}+\sqrt{(n-2)\left[2 F(G)-2\left(\frac{2 S O(G)}{n}\right)^{2}\right]}
$$

which, again is analogous to another Koolen-Moulton bound (Koolen \& Moulton, 2003):

$$
\operatorname{En}(G) \leq \frac{4 m}{n}+\sqrt{2(n-2)\left[m-\left(\frac{2 m}{n}\right)^{2}\right]} .
$$

Proof. Theorem 3, valid for bipartite graphs, is deduced in an analogous manner as Theorem 2, by starting with

$$
\sum_{i=2}^{n-1} \sum_{j=2}^{n-1}\left(\left|\sigma_{i}\right|-\left|\sigma_{j}\right|\right)^{2} \geq 0
$$

and by taking into account that for bipartite graphs $\left|\sigma_{i}\right|=\left|\sigma_{n}\right|$. 


\section{References}

Alikhani, S. \& Ghanbari, N. 2021. Sombor index of polymers. MATCH Communications in Mathematical and in Computer Chemistry, 86, pp.715-728.

Bondy, J. A. \& Murty, U.S.R. 1976. Graph Theory with Applications. New York: Macmillan Press. ISBN: 0-444-19451-7.

Cruz, R. \&, Rada, J. 2021. Extremal values of the Sombor index in unicyclic and bicyclic graphs. Journal of Mathematical Chemistry, 59, pp.1098-1116. Available at: https://doi.org/10.1007/s10910-021-01232-8.

Cvetković, D., Rowlinson, P. \& Simić, K. 2010. An Introduction to the Theory of Graph Spectra. Cambridge: Cambridge University Press. ISBN: 9780521134088.

Das, K.C., Gutman, I., Milovanović, I., Milovanović, E. \& Furtula, B. 2018. Degree-based energies of graphs. Linear Algebra and its Applications, 554, pp.185-204. Available at: https://doi.org/10.1016/j.laa.2018.05.027.

Došlić, T., Reti, T. \& Ali, A. 2021. On the structure of graphs with integer Sombor indices. Discrete Mathematics Letters, 7, pp.1-4. Available at: https://doi.org/10.47443/dml.2021.0012.

Furtula, B. \& Gutman, I. 2015. A forgotten topological index. Journal of Mathematical Chemistry, 53, pp.1184-1190. Available at: https://doi.org/10.1007/s10910-015-0480-z.

Gutman, I. 2021. Geometric approach to degree-based topological indices: Sombor indices. MATCH Communications in Mathematical and in Computer Chemistry, 86, pp.11-16.

Harary, F. 1969. Graph Theory. Reading: Addison-Wesley. ISBN: 9780201410334.

Horoldagva, B. \& Xu, C. 2021. On Sombor index of graphs. MATCH Communications in Mathematical and in Computer Chemistry, 86, pp.793-713.

Koolen, J. \& Moulton, V. 2001. Maximal energy graphs. Advances in Applied Mathematics, 26(1), pp.47-52. Available at: https://doi.org/10.1006/aama.2000.0705.

Koolen, J. \& Moulton, V. 2003. Maximal energy bipartite graphs. Graphs and Combinatorics, 19, pp.131-135. Available at: https://doi.org/10.1007/s00373-002-0487-7.

Kulli, V.R. 2020. Graph indices. In: Pal, M., Samanta, S. \& Pal, A. (Eds.), Handbook of Research of Advanced Applications of Graph Theory in Modern Society, pp.66-91. Hershey, USA: IGI Global. Available at: https://doi.org/10.4018/978-1-5225-9380-5.ch003.

Kulli, V.R. 2021. Sombor index of certain graph operators. International Journal of Engineering Sciences \& Research Technology, 10(1), pp.127-134. Available at: https://doi.org/10.29121/ijesrt.v10.i1.2021.12.

Li, X., Shi, Y. \& Gutman, I. 2012. Introduction. In: Graph Energy, pp.1-9. New York, NY: Springer Science and Business Media LLC. Available at: https://doi.org/10.1007/978-1-4614-4220-2_1. 
Li, X. \& Wang, Z. 2021. Trees with extremal spectral radius of weighted adjacency matrices among trees weighted by degree-based indices. Linear Algebra and Its Applications, 620, pp.61-75. Available at: https://doi.org/10.1016/j.laa.2021.02.023.

McClelland, B.J. 1971. Properties of the latent roots of a matrix: The estimation of $\pi$-electron energies. Journal of Chemical Physics, 54(2), pp.640643. Available at: https://doi.org/10.1063/1.1674889.

Shao, Y., Gao, Y., Gao, W. \& Zhao, X. 2021. Degree-based energies of trees. Linear Algebra and Its Applications, 621, pp.18-28. Available at: https://doi.org/10.1016/j.laa.2021.03.009.

Todeschini, R. \& Consonni, V. 2009. Molecular Descriptors for Chemoinformatics. Weinheim: Wiley-VCH. ISBN: 978-3-527-31852-0.

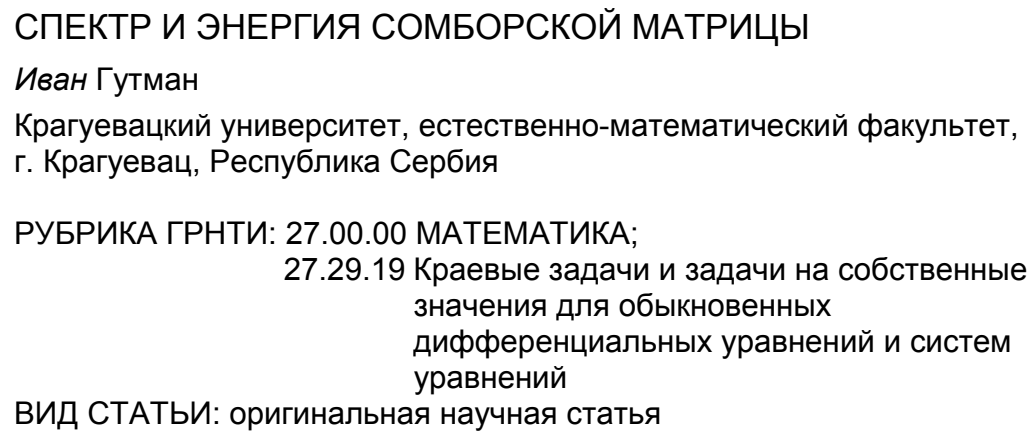

Резюме:

Введение/цель: Сомборская матрица выведена из индекса Сомбора на основании степени вершин. В данной статье представлены спектральные свойства сомборской матрицы.

Результаты: Получены равенства и неравенства собственных значений сомбоской матрицы, из которых выведены два фундаментальных ограничения сомборской энергии (= энергии сомборской матрицы). Данные ограничения зависят от индекса Сомбора и от так называемого «забытого» топологического индекса.

Выводы: Результаты исследования, представленные в данной статье, вносят вклад в спектральную теорию сомборской матрицы, а также в общую спектральную теорию матрии, связанных с инвариантами графов, основанных на степени вершин.

Ключевые слова: Сомборская матрица, энергия Сомбора, индекс Сомбора, инварианты графра, зависящие от степени вершин, спектр (матрицы). 


\section{СПЕКТАР И ЕНЕРГИЈА СОМБОРСКЕ МАТРИЦЕ}

Иван Гутман

Универзитет у Крагујевцу, Природно-математички факултет, Крагујевац, Република Србија

ОБЛАСТ: математика

ВРСТА ЧЛАНКА: оригинални научни рад

Сажетак:

Увод/циљ: Сомборска матрица зависна је од степена чворова, а изведена је из сомборског индекса. У раду су приказане неке њене спектралне особине.

Резултати: Добијене су једнакости и неједнакости за сопствене вредности сомборске матрице. Из њих су изведене две фундаменталне границе за сомборску енергију (енергија сомборске матрище). Ове границе зависе од сомборског индекса, као и од такозваног „заборављеног” тополошког индекса.

Закључак: Резултати изложени у раду представљају допринос спектралној теорији сомборске матрице, као и опитој теорији спектара матрица зависних од степена чворова.

Кључне речи: сомборска матрица, сомборска енергија, сомборски индекс, инваријанте зависне од степена чворова, спектар (матрице).

Paper received on / Дата получения работы / Датум пријема чланка: 25.04.2021. Manuscript corrections submitted on / Дата получения исправленной версии работы / Датум достављања исправки рукописа: 03.05.2021.

Paper accepted for publishing on / Дата окончательного согласования работы / Датум коначног прихватања чланка за објављивање: 05.05.2021.

(c) 2021 The Author. Published by Vojnotehnički glasnik / Military Technical Courier (www.vtg.mod.gov.rs, втг.мо.упр.срб). This article is an open access article distributed under the terms and conditions of the Creative Commons Attribution license (http://creativecommons.org/licenses/by/3.0/rs/).

( 2021 Автор. Опубликовано в «Военно-технический вестник / Vojnotehnički glasnik / Military Technical Courier» (www.vtg.mod.gov.rs, втг.мо.упр.срб). Данная статья в открытом доступе и распространяется в соответствии с лицензией «Creative Commons» (http://creativecommons.org/licenses/by/3.0/rs/).

(c) 2021 Аутор. Објавио Војнотехнички гласник / Vojnotehnički glasnik / Military Technical Courier (www.vtg.mod.gov.rs, втг.мо.упр.срб). Ово је чланак отвореног приступа и дистрибуира се у складу са Creative Commons licencom (http://creativecommons.org/licenses/by/3.0/rs/).

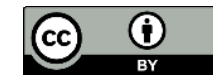

